\title{
Epistemology of mobile journalism. A review
}

\author{
João Canavilhas
}

Nota: Este artículo se puede leer en español en:

http://www.profesionaldelainformacion.com/contenidos/2021/ene/canavilhas_es.pdf

How to cite this article:

Canavilhas, João (2021). "Epistemology of mobile journalism. A review". Profesional de la información, v. 30, n. 1, e300103.

https://doi.org/10.3145/epi.2021.ene.03

Invited manuscript received on December $10^{\text {th }}, 2020$

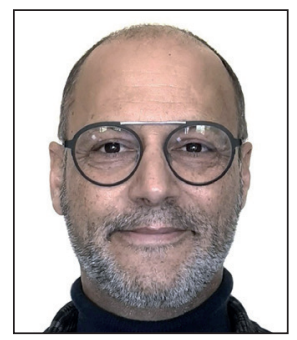

\author{
João Canavilhas \\ https://orcid.org/0000-0002-2394-5264 \\ Universidade da Beira Interior, Departamento de \\ Comunicação, Filosofia e Política I \\ LabCom - Comunicação e Artes \\ Av. Marquês d'Avila e Bolama \\ 6200-001 Covilhã, Portugal \\ jc@ubi.pt
}

\begin{abstract}
The fast and global way which has characterized the presence of mobile phones in society has sparked the interest of several sectors of activity, including journalism. From the early stages of production to distribution, and then through the characteristics of content and consumption patterns, numerous changes have been introduced by these mobile devices in an activity that has been undergoing one of the most uncertain moments in its long history. This uncertainty has stemmed from the decrease in income which was caused by the emergence of new competitors, such as the online press and social networks. This bibliographic review aims at identifying the changes caused by smartphones in the production distribution and consumption of news, analyzing its effect on the epistemology of journalism. We attempt to ascertain if the increasing influence of mobile technologies in the journalistic activity has changed its nature, improving the production of knowledge. Upon closer reading of the bibliography, it can be concluded that the versatility of mobile devices has facilitated a set of new possibilities not only for journalists, namely more autonomy and a reduction in the time spent between the event and the publication, but also for consumers, who can do a mobile and personalized consumption on their screens. Due to its ability to continuously adapt to the rhythm of contemporary society, mobile journalism has become more universal and has been confirmed as a form of knowledge insofar as it responds more effectively to consumers' expectations, in particular young people's, who are moving away from journalism and thus prevent the generational renewal of readers, something which is fundamental for the media business model.
\end{abstract}

\section{Keywords}

Mobile journalism; Epistemology; Journalism; Digital journalism: Mobility; Mobile phones; Smartphones; News; Digital communication; Internet; Apps; Review article.

\section{Introduction}

Having been considered the seventh mass media (Ahonen, 2008), the mobile phone has conquered a central place in current daily life because it is a metadevice that combines several functions into an object of personal use, ubiquitous and permanently connected (Aguado; Martínez, 2006). These characteristics have allowed the mobile phone to be easily integrated in the daily life of human beings (Jensen, 2013).

Unsurprisingly, the success of mobile devices caught the attention of newspaper companies, which, witnessing the exponential growth of the penetration rates, realized that news consumption on these devices opened a new channel, a fact confirmed by the migration of the public to these platforms, which has made these devices become the audience's preferred medium for receiving news (Walker, 2019). 
Through the appropriation of the new media, journalism began to undertake changes in the production, distribution and consumption of the news (Da-Silva, 2015), a situation that brings us to the fundamental question in this work: does the introduction of mobile devices in the journalistic process have epistemological implications in this activity?

In order to answer this question, it is important to begin by analyzing the epistemology of the activity itself, a topic that has been widely discussed over the decades. As McNair (1998) claims

"the form and content of journalism is crucially determined by the available technology of newsgathering, production, and dissemination" (p. 125),

so the way in which mobile technologies broke out and took root in society justifies a debate about epistemology in the current technological reality.

Epistemological discussions about journalism are not new. Authors from diverse nationalities (Park, 1940; 2008; Meditsch; 1997; Ekström; Westlund, 2019) argue that journalism is a form of knowledge, although they represent reality in a different way than Sciences or Philosophy do, for instance (Tambosi, 2003).

Park $(1940 ; 2008)$ seeks to establish a difference between "knowledge of" and "knowledge about", framing journalism at a point of intersection between the lesser rigor of the first and the depth of the second. In spite of this, the fact that news information is objective, true and collected in a rigorous way following ethical and deontological principles defined in professional codes makes the author consider journalism as a form of knowledge, a situation reinforced by other authors who demonstrate that exists a connection between the levels of public knowledge patterns and the news treatment (Schroder; Larsen, 2009). Harré (1984) states that being a social activity, science is developed from people to people and its results have a social use. Talking about news, his social use is scrutinized and discussed, shapes public opinion and fulfills the relevant mission of providing guidance to man and society (Park, 1940; 2008). As a social beacon, journalistic information is essential to ensure the smooth functioning of democracies because it helps citizens choose the most appropriate policies and hence, they will seek to improve societies, as with scientific knowledge.

Meditsch (1997) discusses the pros and cons of journalism as a form of knowledge concluding that the weaknesses resulting from the very nature of the activity limits the universality of the conclusions because it can serve both to reproduce other knowledge or to degrade it. The author defends journalism as a form of knowledge due to its scientific and philosophical framework in traditional areas, such as Sociology or Psychology, but also because this dimension implies a greater demand in relation to the contents and to those who produce or reproduce them, in a logic of strictness of what is required for scientific knowledge.

Ekström and Westlund (2019) reinforce the importance of this aspect by saying that

"journalism is among the most influential knowledge-producing institutions in modern society, associated with high claims of providing relevant, accurate, and verified public knowledge on a daily basis" (p. 1).

In addition, this knowledge is encoded in a medium language that aims to facilitate its understanding by the broad and heterogeneous public characteristic of the mass media, something that differs from the knowledge produced by scientists.

It can be argued that the scientist produces science while the journalist produces information, but it is necessary to consider that

"science is not just a set of knowledge governed by the judgments of reason and experience. It is also linked to a cultural and axiological context and rests on values admitted by the culture in which it is inserted" (Paty, 1997, p. 3).

Therefore, this author considers that the universality of knowledge must be analyzed as a work of thought, as an activity of a social nature or as a science and technology system, with the repercussions that they have in the community. Paty (1997) also states that while the first two dimensions can be found in all eras and in all sciences, understood as a system of knowledge. The relationship between science and technology is more recent, especially since the $17^{\text {th }}$ century after the link between science and technology. It is in this connection that journalism is embedded since its products -the news- are developed using methodologies similar to those of science, using a set of techniques that have evolved to follow technological progress.

In this sense, the scientific-technological dimension allows an epistemological approach to discuss whether mobile technologies have changed the way journalistic knowledge is produced and their ideal of universality has been altered. This issue is particularly important because it is in the preservation of this ideal audience that Journalism finds one of its main social justifications: that of maintaining the communicability between the physicist, the lawyer, the worker and the phi- 
losopher. While science evolves by rewriting knowledge of common sense in formal and esoteric languages, Journalism works in the opposite direction (Meditsch, 1997).

If the mass media produce content for wide audiences made up of non-specialists (Ortega-Gutiérrez; Humanes, 2000) and mobile consumption allows personalized consumption, to what extent does this personalization not contradict the characteristic universality of knowledge? This is a significant question in our epistemological discussion.

A second epistemological approach can be made through a fundamental concept in journalism -objectivity- which has an epistemic and an ontological sense, both of which must be analyzed in the person/object dialectics (Tambosi, 2003):

"the epistemic meaning applies to affirmations, to the way of knowing, (objective knowledge), while the ontological concerns the way of existence of things in the world (the objective reality)" (p. 439).

Thus, in epistemic terms, objectivity coincides with the truth, that is, there must be a confirmable fact that does not need any intermediation for its verification. Subjectivity, on the other hand, is related to the introduction of the human factor in the story, which inserts personal filters, adding elements to the narration.

In the ontological sense, objectivity is marked by the real and physical existence of people/objects or by raw facts independent of the observer, while subjectivity is more linked to intuitions/feelings that can only be confirmed by the person who feels or, in the second example, by social/institutional facts already contextualized by the observer within their social reality (Tambosi, 2003).

In both senses, objectivity is always linked to a visible, palpable or confirmable reality, while subjectivity is directly related to the belief that a report corresponds to the truth of the facts narrated by an observer.

Considering epistemology as the study of knowledge and the justification of belief (Dancy, 1985), we can say that knowledge is a true belief because it has been confirmed. The belief is confirmed if the fact reported coincides with reality, which can happen in two ways: by the dissolution of the subjectivity introduced by the observer in the transmission of that same report, making it more natural and less social, or by reducing the space between the event and its report. The first way refers to the discussion on the role of the observer in the reality codification process, repeating Tambosi's (2003) argumentation regarding subjectivity. On the other hand, the second introduces a new variable -the question of space/time between the moment of the event and its report-. In this field, mobile devices influence the process to the extent that they compress the news process by accelerating production, even allowing its cancellation thanks to the possibility of making live broadcasts. This change leads to the discussion about the new role of the observer, but also to others related to the acceleration of information and the consequent reduction in its quality.

In a time where users live immersed in information, smartphones have changed the way we use and consume the news, creating a renewed ecosystem framed by new challenges to all stakeholders (López-García et al., 2020). This paper aims to address the challenges posed by mobility to journalism, which is only possible if we do not ignore the changes observed in the media ecosystem.

\section{A changing ecosystem}

The introduction of a new species in a biological ecosystem causes imbalances and can lead to the disappearance of native ones. The fact that mobile devices have quickly become the preferred platform for news consumption (Nelson, 2019) has made it even more important to look at the ecosystem because adapting to a new reality is essential if the ancient species want to survive and can force newcomers to follow the rules of that ecosystem. Only in this way is it possible to achieve a rebalancing that ensures the survival of the ecosystem itself.

The switch from the biological reality to the mass media field led Canavilhas $(2011 ; 2015)$ to propose three types of factors, in other words, three fields of investigation that allow us to analyse what happened when a new media arises:

- intermediatic factors (study of the mass media and their relations),

- contextual factors (consumption environments), and

- techno-environmental factors (consumption interfaces and user action on the system itself).

That means we have three areas that allow us to analyze mobile journalism from three perspectives. The most technological, as stated by Postman (1979), defines the mass media as machines that transmit information and encode it according to its characteristics. Therefore, it is important to dissect mobile devices, especially smartphones in order to identify the reasons that transformed it into the mass media that quickly became the most popular.

\subsection{The new media and its relations}

One of the various reasons that justify the success of smartphones is the fact that they are a mobile way to access the internet (Aguado; Martínez, 2006; Westlund, 2012; Canavilhas et al., 2020). For that reason, it makes sense to start this point with a reference to the internet, which in October 2020 reached 4,929 million users reaching a worldwide penetration rate of $63.2 \%$ and registering a growth of $1,266 \%$ since 2000 . 
Mobile access through browsers or applications (apps) greatly contributed to increase these numbers, a fact which led the journalistic market to think of the new platform as an opportunity for this activity.

The success of mobile phones is due to the combination of several aspects. Firstly, the fact that these devices are carried close to the body (Ling, 1997) means they are perceived as a human extension (Lasen, 2001; Gant; Kiesler, 2001) and therefore have a strong and emotional connection to their user (Katz; Aarhus, 2002). Secondly, because mobile phones convey the feeling of personal security

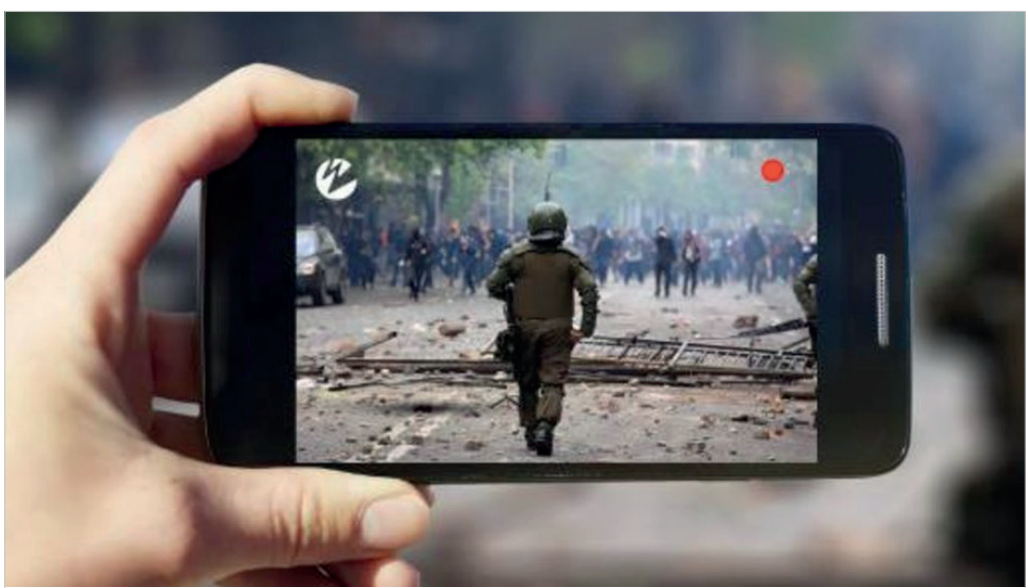

https://www.wowza.com/live-video-streaming/broadcast-and-OTT

to their users (Dimmick; Sikand; Patterson, 1994), enabling integration in groups, communication with friends (Geser, 2004; Quinn; Oldmeadow, 2013), mobility, fun and permanent connection (Lorente, 2002; Linger, 2002).

In the field of journalism, mobile phones in their most advanced technological version - smartphones- not only facilitate media consumption in any context (Peters, 2012), but also offer a dynamic multimedia continuum (Barbosa, 2013) and allow the appearance of new and more appealing journalistic narratives for the young audience. These prefer the new media (Raeymaeckers, 2004; Bernal, 2009; Casero-Ripollés, 2012) which offer them more attractive multimedia content (Huang, 2009).

Without young people, the market segment that ensures the renewal of the audience, journalism would lose sustainability, because although it has a fundamental social role, it is an economic activity that depends on demand and has a stable business model based on the segmentation of audiences (Picard, 2013). For this reason, journalism has been forced to adapt quickly to economic and technological changes, hence the innovation in product, distribution channels and content is essential to ensure the future (Saad, 2011; Peters; Broersma, 2013).

The mobile communications service providers themselves have changed from a "telecom model", based on the sale of voice services, to a "software model" in which the focus is placed on exploring the computational characteristics of the devices (Castellet; Feijóo, 2013) by exploiting the vast offer on the internet. Thus, a device that was born for interpersonal communication has become much more than that: nowadays the smartphone is an extension of our body, a multifunction device and a privileged channel for access to internet, surpassing its initial function -oral communication- to a secondary level due to technological innovations that combined the functions of a computer, camera, GPS, calculator, clock, music player or credit card in one device, among others (Klemens, 2010; Canavilhas et al., 2020).

All this justifies the success of smartphones, a product whose sales increased between 2008 and 2016, stabilizing but not declining. This interruption of almost one decade in sales growth is due to the saturation of some markets and to a slower innovation dynamics (Richter, 2019). Nevertheless, the mobile devices continue to be the most transversal medium since their distribution in the various geographies of the globe is the most balanced of all mass media. For all these reasons, smartphones an object of innovation, change, and renovation of the older media (Goggin; Hjorth, 2009) offering a wide range of possibilities for bringing old and young media together in one device (Madianou; Miller, 2012).

\subsection{Mobile consumption environments}

Space is a fundamental variable in the field of journalism. We can refer to space as distance, which has always been one of the obstacles to distribution but, in this case, we are mainly interested in space as a consumer environment since mobile devices are characterized precisely by their ability to ensure the contextual users news consumption (Silva-Rodríguez, 2013).

The printed press, for instance, has varied their consumption environments: from the times of low literacy when the illiterate learned of the news in the reading clubs until today, consumption has gone from a static assembly to an individual and mobile one. In this case, the phenomenon occurred more because of the increase in literacy rates than because of the characteristics of the newspaper that always has been portable. The radio has also undergone a progressive process, with mobility arising thanks to the appearance of personal receivers and later through its inclusion in automobiles. As far as television is concerned, mobility has also existed since the appearance of digital terrestrial television (DTT), but the mobile consumption of this medium has only truly grown with smartphones.

This culture of mobility (Kischinhevsky, 2009) compels us to rethink information consumption in different contexts. If places cannot be separated from their context of experience (Santaella, 2007), the fact that this experience now takes place anywhere due to the ubiquity offered by the smartphone (Goggin; Hjorth, 2009; Struckmann; Karnowski, 2016), opens up new perspectives for research. 
If until now all mass media had started in group consumption and only later evolved towards individual consumption, in the case of smartphones we are faced with a different situation because the collective spaces they have nothing of collective once they allow a consumption in an individual screen (Santaella, 2007),

This means that even though one is within a group, consumption on the smartphone is individual, which introduces two variables that journalism needs to learn how to deal with: mobility, and personal consumption. In addition to these two variables, we must add a third one -the context- because news consumption is something that occurs in a specific place (Peters, 2012). That means that news consumption in mobility implies changes in news production, as we will see later.

\subsection{Consumption interfaces and user role on the ecosystem}

One of the main changes in the techno-environmental factors was the hegemony of small screens as an interface for news consumption. Previous mass media -press, radio and television- started to be consumed on smartphones, tablets and wearables, such as smartwatches and glasses (e.g, Google Glass). More recently, personal assistants (Alexa, Siri, etc.) added the possibility of interacting via voice replacing the usual touch interfaces of mobile devices.

The media interface is assumed here as a place of interaction that evolves and co-evolves with its users because it is a space for innovation (Scolari, 2018). In the case of smartphones, the design of this type of interface is more difficult due to the small size of the interaction surface and the fact that users move between different contexts (Gong; Tarasewich, 2004) while interacting. This is due to the fact that in addition to portability these devices have in common one characteristic: they are connected to the internet,

“(...) a multimedia channel, which tends to emulate and integrate many older media, blurring their boundaries without really supplanting them" (Pauwels, 2005, p. 609).

As stated by Goggin and Hjorth (2009), the characteristics of mobile media provide new ways of seeing, reading, listening and touching, transporting the media process to new contexts of consumption and enabling new forms of participation for the people.

These ways of participation have grown enormously with Web 2.0, a term created by O'Reilly Media in 2004 to mark a new level on the Web in which users have come to have a more interactive and participatory role through the production of information on blogs, video platforms, social networks, etc. Journalism ceased to be the centre of the media system, and began to share this space with users, the so-called prosumers (Jenkins, 2008) or "produsers" (Bruns, 2008).

Furthermore, the role of consumers is not limited to participation, since the level of demand in relation to journalism has also risen:

"The mobile phone, in the hands of a digitally literate population, has fundamentally changed the relationship between the media and consumers of news. Under the old model, journalists would tell the public what they needed to know, when they "needed" to know it (i.e., when it suited them). Today, consumers of news pull down what they need, when they need it and how they need it" (Jukes, 2013, p. 5).

This set of technological changes has radically changed the way we interact (Geser, 2004), which has repercussions on the media ecosystem, as we will see later.

\section{Mobile phone as a journalistic tool: production}

Although an interesting amount of scientific production in the field of mobile journalism can already be accessed, the lack of analytical and practical studies on the stages of production, distribution and reception of journalistic content on mobile devices is still a reality (López-García et al., 2020).

In the field of journalistic production, one of the most studied areas has been the use of smartphones as a new tool (Bivens, 2008; Westlund, 2013; Andrade et al., 2015) or the analysis of experiences made with mobile devices (Blankenship, 2016; Mills et al., 2012). This set of studies has arisen due to the fact since very early it became evident that the cell phone challenges the journalism practices (Mielniczuk, 2013).

One of the first changes related to the appearance of mobile devices, in this case still with feature phones, was the possibility of establishing permanent contact between the newsroom and the journalist who collects information at the events. The journalist sent to the place of the event is so absorbed by his work that he loses the notion of the more global context, missing new information related to that event that comes to the newsrooms through different sources. Mobility communication facilitated by feature phones now allows the newsroom to send new information to the journalist that opens new paths of investigation and allows questions to interveners about data that have emerged but are unknown to those who are at the place where something is happening.

The introduction of this factor brings an epistemological change because the ontological subjectivity -the existence of a raw fact about which the journalist was collecting information in a certain perspective- can suffer a change motivated by the arrival of new information that leads the journalist to ask new questions to stakeholders or even interviewing new characters. With these quotes, the journalist seeks to make his work more objective by transferring responsibility for the information to the interviewees (Zelizer, 1995) who, when confronted with new information, confirm or reject it, thus giving more credibility to the news. 
Another important change was the replacement of image equipment, with digital cameras being replaced by smartphones. In addition to the miniaturization of equipment, the fact that they are discrete and easy to handle devices (Maccise; Marai, 2017) made it easier to obtain images in spaces where journalists were often prevented from taking them. With this change, it became possible to offer information consumers similar perspectives to those who have direct participants in events.

In a first moment, there was some distrust from the image professionals in relation to the use of smartphones in capturing images (Guerrero-García; Palomo, 2015). However, the connection between smartphone manufacturers and camera or lens manufacturers, such as Leica or Zeiss, together with the increase in the number of cameras per device, enhanced the photographic capabilities of these devices transforming them into high quality machines. Moreover, native applications (apps) were added, which made it easier to edit the images on the device itself and send them straight to the newsroom. A similar process occurred with sound and video, a situation that transformed those equipment's into true personal editing studies, making the physical presence of these professionals in the newsroom unnecessary (Da-Silva, 2014).

The aesthetics of photography has changed as well (Germen, 2014) due to the fact that it has become possible to take images anywhere, at any time and with automatic shutters that in thousands of seconds offer thousands of perspectives on the object or situation photographed. If in part this change had already occurred with the appearance of digital cameras, the fact that the images started to be made with a common object which we carry around at all times further enhanced this possibility.

Not all types of article formats and multimedia content from the news site could be auto-directed to mobile news platforms. Journalists started to think one step ahead when reporting on breaking news to ensure that it was also displayed on mobile devices (Westlund, 2013, p. 15).

"The omnipresence of smartphones as imaging devices has a strong impact on the fact that they encourage, help us to take photos in places, instances, settings, occasions, we would not otherwise think of photographing" (Germen, 2014, p. 307).

Once again, we can observe ontological changes because no longer are there limitations in the number of images that could be taken. From the 12, 24 or 36 photos of the analogic system, we switched to digital cameras with limited capacity and, later, to usable smartphones that allow us to quickly capture an unlimited number of images that are immediately available in the cloud. Not being concerned with spatial limits, the journalist tries to make the captured image convey reality the best way possible. Although there is always human intentionality resulting from the photographer's positioning in relation to the space where the action takes place and the professional's own aesthetic criteria, the increase in the number of images captured increases the probability that some of these images reproduce reality more naturally.

In the field of the moving image, in addition to the changes related to capturing and editing common to photography, another important change appears: the generalization of live broadcasts. What previously required expensive and complex production, such as outdoor cars, human resources, satellite rental, etc., became possible with a simple device for personal use and without the need for more human resources than the journalist, thanks to devices and high-speed networks. Here too, more objectivity is introduced, both in epistemic and ontological terms. In the first case because being live the fact is confirmed; in the second, because in being raw images we have something that ontologically is the mere transmission of a real event.

In addition to the evolution of the devices themselves, the development of the App Stores deserves mention, as it is this change that allows the treatment of raw content. Since the importance of improving the processing and storage capacities of the equipment and the permanent connection to the internet was indisputable, the role of apps cannot be underestimated because they allowed smartphones to be more than a device for capturing and sending raw content (Goeldi, 2018).

“Initially planted as a secondary complement to platforms, virtual application tiers ('app stores', with Apple's permission) have in only four years been converted in the axis on which the main transformations of the mobile ecosystem and its development horizons move" (Aguado; Castellet, 2013, p. 41).

These apps, which also influenced consumption, transformed smartphones into a mobile and personal newsroom by allowing them to edit the content, its composition and by making it available to the public.

This set of changes has given more strength to the so-called MOJO, a way to telling stories by journalists that they are trained and equipped for being mobile and technically autonomous (Podger, 2018). Initially called backpack journalism (Steven, 2002; Strong; Zafra, 2016), in reference to the possibility of a journalist being autonomous thanks to a backpack with a laptop computer, a digital camera and a microphone, it was switched to pocket journalism (Renó, 2011; Twist, 2005) that allows you to do all this with one device: a smartphone. With these mobile devices, journalists started to do their work more quickly due to the ease of handling, transport and mobility (Maccise; Marai, 2017).

Another aspect where changes have occurred with implications in the field of production was the participation of users in the news process. The people formerly known as the audience (Rosen, 2006) gained a place in the new media ecosys- 
tem leading to the emergence of movements such as citizen journalism (Gillmor, 2006; Meso-Ayerdi, 2005), participatory journalism (Bowman; Willis, 2003; Hermida; Thurman, 2010) or collaborative journalism (Glaser, 2004), among others. This movement, born with Web 2.0, has evolved over the years and has challenged mainstream media with the emergence of new informational players that aroused the interest of users (Hermida; Thurman, 2010; Newman, 2012; Sasseen; Olmstead; Mitchell, 2013). Mobile devices have given citizens even more strength since they have made it possible to improve the technological capabilities of content production with a reduced investment in a device already used in their daily lives.

The importance of this phenomenon in the scope of this work is not so much the role of citizens as producers of information, but as providers of information, that is, we are not interested in citizens' participation as playground spaces, but those in which the citizen works as a source (Domingo, 2011), with the media themselves asking for the collaboration of users, sending complaints, as it happened on the Web, but now encouraging the submission of photos and videos. This participation allows the creation of a giant network of collaborators, which, due to its dispersion in the territory, enables access to any event more quickly, even though the quality of the information collected may be lower. Any sudden event that occurs can be reported with the use of amateur images captured by citizens who were on the spot at the time, a situation that can be seen as an approximation to objectivity in the ontological sense, since the citizen is limited to trying to capture the moment with no other purpose than to register a momentary reality.

The work inside newsrooms has also undergone changes because the production of mobile news requires interdisciplinary work among journalists, designers and programmers, among other specialists (Palacios et al., 2015). If there is a tendency abroad for the individualization of work, within the newsroom the movement goes exactly in the opposite direction since the contents are more complex and require the participation of so-called techno-actors in the production process that they assume to have the task of solving technical problems that allow the appearance of more appealing types of contents (Canavilhas et al., 2014). Each professional tries to enhance the characteristics related to his work in order to provide a good user experience, but he underlines that there are epistemic distances between the logic of computational thinking, the artistic conception of visual culture and the textual and contextual journalistic model. The result of this professional miscegenation was the birth of new content formats and new ways of storytelling (data journalism; parallax reporting) that differentiate web and mobile journalism from that done in other media. This situation changes the epistemological nature of the journalistic product insofar as by improving the way of transmitting complex information contributes to a consolidation of knowledge.

\section{Mobile devices as a consumption platform: content and distribution}

Among the changes resulting from the integration of mobile devices in journalism, the way the content has changed (Parry, 2011) is one of the most visible to the public.

A first alteration is related to the very nature of the content, which started out as monomedia and currently offer all types of multimedia content (Salaverría, 2014) that portray situations in a more realistic way (Zelizer, 2019).

In parallel with this change, the growth in consumption on mobile devices led to an increase in the supply of breaking news:

"Not all types of article formats and multimedia content from the news site could be auto-directed to mobile news platforms. Journalists started to think one step ahead when reporting on breaking news to ensure that it was also displayed on mobile devices" (Westlund, 2013, p. 15).

This offer encouraged a trend towards the consumptions of short and contextless news (Molyneux, 2018), something that was already stimulated by the characteristics of the devices themselves, namely the mobility and the reduced dimensions of the screens of these devices.

It is also the technological characteristics of smartphones that enable the consumption of multimedia content with different degrees of complexity, from the simplest ones that cross various types of content (text, sound, image), to the most complex, such as immersive content (Domínguez-Martín, 2015; Aitamurto et al., 2020) of virtual reality, augmented reality, 360 contents, etc. With or without recourse to cardboards or HMD (head-mounted display), immersive content is one of the great news brought by smartphones and has originated in the first immersive journalistic production in virtual reality: "Hunger in Los Angeles", by De-la-Peña et al. (2010).

This kind of immersive content, which technically and stylistically is still in its early stages, offers sensory experiences through the sensation of presence in a real recreated space or in an imaginary space created for that purpose (Owen et al., 2015), using technological, aesthetic and interactive resources to eliminate physical boundaries in a sensorial way (Domínguez-Martín, 2015). By creating a strong sense of presence (Aitamurto et al., 2020), immersive content allows users to become more emotionally involved with the content (Grau, 2007), which represents a differentiating feature of mobile journalism in relation to other visual content and has an economic potential to be explored.

Despite this potential, newspapers' greatest bet has been on 360 video content, perhaps because they are technically simpler and cheaper. By privileging spatial immersion over sensory immersion, journalism reduces both the level and the emotional involvement, preventing total immersion (Colussi; Assunção-Reis, 2020) and thus destroying one of its differentiating characteristics. 


\subsection{Distribution for mobile devices}

At a second level of changes, we already have a mixture of the content and distribution of information. Some of these changes had already occurred with the appearance of journalism on the Web, but they gained a new impetus with the possibility of distributing information to a device for personal use that is permanently connected to the network (Aguado; Martínez, 2006).

These mobile devices' potential for the reception of personalized information makes it possible to switch from a mass content distribution to a personalized distribution adjusted to the user's preferences. This possibility of personalizing the information may result from the user's own choices, who agrees to receive notifications from the media with the highlights of the day or updated information. However, it can also result from reading our browsing habits made through trackers (cookies) installed in browsers that linked to powerful databases cross our personal information to offer a multitude of products and services.

It is undeniable that our digital footprint opens the door to a personalized distribution of information, a situation that has some advantages for companies, but it also has many disadvantages for consumers and society. From the perspective of media companies, the possibility of offering us the information they know indicates our preference is an advantage because it responds to our difficulty in managing the enormous amount of information available, a situation that has benefited curators such as Google and Facebook (Nelson, 2020). In addition to this advantage, there is the possibility of selling our data and preferences to advertisers.

From the consumer's perspective, the advantage associated with personalizing information brings some loss of privacy and, in a mix of personal and social disadvantage, its incarceration in an information bubble (Pariser, 2011) that limits its global and contextual view.

Referring to current times as an "era of context", Scoble and Israel (2014) argue that there are five forces available to each user when they touch a screen with their fingers:

- mobile devices,

- social networks,

- data,

- sensors, and

- locations.

The authors believe that these forces are changing our experience as buyers, users, patients or travellers, while also changing the business world. Specifically in the field of journalism, Aguado and Castellet (2013) state that the news can take advantage of the geolocation, context of use and Augmented Reality to increase the quality of the content. Schmitz-Weiss (2015) provides the example of weather information apps to illustrate the advantages perceived by consumers in the consumption of geolocalized information, drawing attention to what she called spatial journalism.

The routines of users' contact with the news have also changed. On the one hand, the massive use of mobile devices deepens the transition from a "pull system" to a "push system" (Fidalgo; Canavilhas, 2009), in other words, it is no longer the user who looks for the information but the information that looks for the user. This change had already occurred with the appearance of information aggregators (Canavilhas; Satuf, 2016), but apps have further underlined this trend. By allowing these apps to send updates on certain topics, the user opens his personal communication channel, receiving information updates at any time without having to look for them. A recent study (Wheatley; Ferrer-Conill, 2020) confirms this trend by showing that push news is a consistent trend in European media distribution strategies, with information being sent during periods of low consumption to keep the consumer permanently connected to the media.

This continuous supply of new information is one of the problems of journalism as knowledge because it implies a speed of production, which in comparison with Science, is much faster and less profound. However, Meditsch (1997) reminds us that speed is a characteristic of modern society, which can represent an advantage in relation to other forms of knowledge in its ability to adapting the social needs.

The speed of journalism became instantaneous (Bradshaw, 2014), changing the periodicity that characterized traditional daily information (newspapers), three to four times a day (TV) or hourly (radios), thus reducing the gap between the moment of the event and its dissemination. This acceleration of information responds to a human need to receive information updates whenever a situation of great social impact occurs (Schneider, 2007). But it also calls into question the hierarchy of values in journalism, demoting the commitment to truth and objectivity to levels below that of instantaneity and overestimating speed (Moretzsohn, 2002). More than the acceleration observed in the production and distribution of information, which is characteristic of journalism and does not alter its epistemological nature, it is the instantaneity that can strike its value as knowledge, as it is less rigorous to fulfil shorter information cycles.

\subsection{Consumption in mobility}

Mobile devices have changed the way users consume news (Westlund; Färdigh, 2015), even if compared to the medium that is closest to them: The Web. Though distribution is made through the same technological infrastructure -the Inter- 
net- consumption either on a computer, or on a smartphone, is different due to the technical characteristics of the devices and mobility, which are common features, despite still displaying notable technical differences, due to the decrease in the size of consumer platforms (Pellanda, 2009).

Although mobility truly started with the miniaturization of radio receivers in the late 1960s, it is with smartphones that consumption truly gains mobility. The radio itself, a pioneer in mobility in electronic devices, felt the need to gain visibility on smartphones to survive in the new ecosystem (Pedrero-Esteban; Herrera-Damas, 2017). With mobile devices, the information requested is provided ant the right time and place (Wolf; Hohlfeld, 2012). This possibility opens a set of potentialities when crossed with the change from group consumption in the living room or cafe to individual and mobile consumption on the smartphone.

With a personal and portable device, users started to take advantage of all available moments to update information, so the typical cyclical consumption marked by the periodicity of the media gave way to an always on consumption in response to the change in distribution, which also became instantaneous, as it was mentioned in the previous point. This is a good example of the way in which the media have quickly adapted to the new consumer's demands, providing information throughout the day instead of waiting for information services with fixed schedules. When compared to older media, daily consumption on mobile devices happens more often, it is distributed over more moments, and sessions are shorter (Molyneux, 2018), a situation that largely relates to consumption on mobility that occurs in public transport or when the consumer is on hold.

This situation reinforces the idea that the consumption context is an important variable in the process. In fact, mobile journalism has enabled users to consume anywhere, anytime and in new content formats adapted to devices (Dimmick et al., 2011). In this new mobile reality, the context assumes a crucial importance because it conditions the emission and presents a potential for economic exploitation. The context is assumed as a multidimensional concept that includes not only the place or time, issues which are more linked to the consumption space, but also other technological and cultural dimensions (Courtois et al., 2013) that influence the process, due to the fact that the mobile news consumption occurs is a specific place (Peters, 2012) with unique characteristics.

The mobility of the consumer makes it possible to send information about the space where the user is, in addition to also facilitating what Canavilhas (2013) calls "divergent content" when moving from multimedia content by juxtaposition, coordination or subordination (Salaverría, 2014 ), for a distribution in which the contents recover their monomedia nature (text, sound or video), but are distributed according to the situation in which the user finds themselves, which can be transmitted by the technologies incorporated in the reception platform. Thanks to the accelerometer and gyroscope, for example, it is possible to know if the user is on the move, whether walking or driving: in this type of situation, the content must be provided in audio format. Another possibility is the use of GPS: locating the user in a space such as a library or a church, for example, the ideal is to send the content in a format without sound, so it is preferable to send the information in textual format. Thus, we would have a contextual distribution of information that can take into account not only the user's location for thematic purposes, but also the ideal format in each situation (Canavilhas, 2013). This divergent distribution is, in essence, a return to the initial nature of each type of content, but it can introduce some subjectivity due to the difficulties in adapting some themes to a certain media language. If multimediality and immersive content can make information more objective, the return to monomedia content goes exactly the opposite way.

\section{Mobile journalism: economic issues}

The negative economic impact of digital journalism on media companies remains a problem that has not yet been resolved during its 25 years of life (Salaverría, 2019). Sharing the same channel, mobile journalism is experiencing the same problem, however there are some untapped potentials.

"The combination of a technological revolution, new (and as yet not fully understood) business rules, and global recession has created, to use the cliché, a 'perfect storm'” (Jukes, 2013, pp. 1-2).

The technological revolution brought new players to the information market, such as Google and Facebook. These are platforms that quickly managed to take the largest share of the advertising market, calling into question the traditional models of journalistic business and leaving the mainstream media in difficulties (Pauwels; Picone, 2012). These platforms have also been joined by free digital publications, blogs and social networks, that also challenge the centrality of traditional media. 
The invasion of mainstream media space by foreign elements has fragmented audiences and created new consumption habits. The new generations moved away from the consumption of information in traditional media (Túñez, 2009; Brites, 2010) and knowing that the future of any business depends on the renewal of its consumers audience, (Lauf, 2001) the loss of young consumers substantially reduces the chances of survival of the media, making it necessary to look for new business models.

The inability of legacy media to attract young people to read news, in conjunction with the flight of audiences to consumption on mobile platforms (Steensen; Westlund, 2020), leads to a bet on mobile devices because journalism must be where the public is. Knowing that smartphones have become a mandatory companion for young people (Cevallos, 2009), it should be a priority develop journalistic work that focuses on such devices, using formats and languages that respond to the expectations of new generations (Costera-Meijer, 2007; Huang, 2009) as this is the only way to renew the reader base.

This scenario prompts Jukes (2013) to say that journalism faces difficult obstacles to overcame because, to the economic problem, it adds the loss of public confidence in its role of watchdog and runs the risks of losing its social relevance and fails to influence public opinion.

Regardless of format or language, journalism aims to build a sense of community and keep the population informed so as to help citizens when they are called to choose their leaders (Kovach; Rosenstiel, 2014). For that, it needs to be consumed, a situation that previously was measurable by using the numbers related to sales and audiences and which nowadays is dispersed by a myriad of metrics. Tools such as Google Analytics or ChartBeat allow the media to know almost everything about their users, a situation that contrasts with the presumed audience from the perception of the journalist or from market studies carried out with samples.

In addition to the exact numbers of audiences measured by these tools, there are also "likes", "shares" and other easily measurable variables that offer a much richer audience than the data available so far and allow the required segmentations by advertisers. The problem is that these new ways of measuring audiences allow us to realize that the media now have an unbeatable competitor in social networks due to the capillarity of their operating model.

Subscriptions to the paper-based newspaper have been replaced by digital subscriptions, constituting an advantage for the digital format due to the easy dissemination, but this audience represents a tiny part of the global audience measured, based on traffic on news sites. Kiosk sales which previously represented most of the audience, still have to find a substitute.

What currently happens in premium journalism models is similar to what happened in the past when people stopped by the kiosks to read the covers and headlines without intending to buy the newspaper. The sales themselves, which were equally used by advertisers to choose newspapers to invest in, have not been replaced by any new model. Clearly this situation brought along economic and social repercussions.

With the exception of successful niche publications (Anderson, 2006) or global newspapers such as The New York Times, whose digital revenues have already surpassed traditional ones (Tracy, 2020), most media bet on the freemium model (free + premium), thus combining the offer of free content with other paid content (Casero-Ripollés, 2010), however, the revenue does not seem to work. Despite this, Anderson (2009) claims mixed models because free brings readers and some of them are supposed to pay to save time for the things they like or for what can give them status. As Gómez-Barroso (2018) highlights, there is still a lack of economic models that explore the personal (public) data available in journalism and in advertising.

The fact that the consumption of mobile devices is personal and takes place on a platform with very advanced technological resources nowadays allows us to have statistics with a higher reliability than any other previous system because it is possible to know what is being consumed, how long for, at what time and where it is being consumed. This situation allows for the transition from traditional financing plans (sales + advertising), to 360 models (Canavilhas et al., 2016) that combine the sale of content per unit of information, new forms of advertising that involve the user, crowdfunding, the sale of apps and the inclusion of digital accesses to the media, not only in the packages sold by ISPs (internet service providers), but also on mobile devices.

The improvement in the economics of the media enterprises would make it possible to combat the precariousness that has become established in the profession, with an impact on the quality of the journalistic product as a form of knowledge.
Portability, ubiquity, media functions of the phone and the "appification" have enabled the transformation of these devices into tools that offer more autonomy to journalists 


\section{Epistemology of mobile journalism}

Mobile journalism is the fastest growing type ofjournalism (Perreault; Stanfield, 2019) and so it has challenged some of the fundamentals of this activity. Despite its close connection to journalism on the Web, mobile journalism has particularities that once again call for the discussion of this activity's epistemology.

In this paper, the changes introduced by mobile devices in journalism have been identified, aiming at understanding which of the various stages of epistemological changes are most evident, if they exist.

In a first epistemological approach, we tried to discuss if journalism produces knowledge. By reading the bibliography it is possible to confirm this hypothesis since mobile journalism follows rigorous work methodologies, is guided by ethical and deontological principles (Park, 1940; 2008), and provides periodically accurate and confirmed knowledge (Ekström; Westlund, 2019).

Another important epistemological discussion is related to objectivity, with an epistemic approach (way of knowing) and an ontological approach (way of existence), following Tambosi's (2003) approach. In the first case, objectivity coincides with truth while subjectivity is related to the intermediary who reports the event. In ontological terms, objectivity is related to the reality or facts independent of the observer, while subjectivity is more linked to the viewer feelings. We try to situate this second discussion in the field of content production, trying to verify what influence mobile devices can have as a professional tool for journalists.

Within the scope of production, it appears that portability, ubiquity, media functions of the phone and the "appification" allowed for the transformation of these devices into tools that offer more autonomy to journalists. Furthermore, smartphones help to decrease the existing space and time that mediates between the event and its publication, reducing human intent and increasing objectivity.

When collecting data, the mobile phone allows for an epistemological change because the fact that it can receive new information from the newsroom when already at the event site allows the introduction of changes in the approach to the interviewee and the stakeholders. On the spot, the journalist can confront the stakeholders with new data and obtain an immediate reaction that he will transcribe as a quote. There is an increase in objectivity here that gives credibility to the news in the face of the growing number of unidentified sources that have appeared in the news. If this advantage allowed by a simple mobile phone adds the possibility to record these statements in audio or video, there is an increase in objectivity and in this case, it is already a gain allowed by smartphones.

Image is also an area where ontological changes can be confirmed. The infinite storage capacity of a smartphone connected to the cloud, combined with the remaining technological potentials of smartphones, allows recording the event from various perspectives, reducing the reporter's intentionality. The combination of the technical capabilities of the devices with the high-speed computer networks also allowed the greatest use of rights, which, being made by a mobile device from a position in the middle of the public, permits an approximation of the content transmitted to reality, which is why, ontologically more objective. With regard to the characteristics of the media, in this case in the field of reception, the most important question lies in a factor that differentiates journalism for mobile devices from traditional journalism: does the possibility of personalizing information due to the characteristics of the medium contradict the universality of knowledge?

Jensen (2013) states that the novelty introduced by mobile devices is the perfect way in which these devices were integrated into daily practices in a synchronous, localized, and individualized way. The integration news consumption patterns in daily routines leads to relative isolation, because although consumers are in the middle of many people, only users can see the small screen. (Van-Damme et al., 2015). However, this personalization is more related to the context of consumption in mobility and to the formats adapted to the devices than to the individualized distribution of content.

The media have been advised to serve the niches well instead of serving the masses poorly (Jarvis, 2009) which in the case of devices gains greater importance because they are personal channels that allow content to be adapted to the consumer. Such a situation does not invalidate the information being used by the community (Harré, 1984) and, thus, remains universal knowledge. As in the specialized press, the more specific the theme is, the more demanding the readers are, and since they are specialists in that subject, demand more depth in the treatment that journalists give to topics.

In web journalism, and with greater accuracy in smartphone journalism, the response to users' expectations assumes a fundamental importance due to the existing technologies for the measurement and knowledge of consumption habits. The metrics currently available make it possible to interpret the data resulting from the measurement of the news item (Henshaw, 2006) with such precision that journalists can better understand their audience, deepen the relationship with it, and adapt the content so that users can use it, identify themselves as truth tellers (Usher, 2018) and, therefore, knowledge producers.

When collecting data, the mobile phone allows for an epistemological change because the fact that it can receive new information from the newsroom when already at the event site allows the introduction of changes in the approach to the interviewee and the stakeholders 
This approach of journalism to science is also made possible by the use of content more suitable for explaining events and phenomena, such as interactive graphics, 360 일 veo, etc. For this, it relies on the participation of the so-called techno-actors, the new figures who gain more presence in the newsrooms. Although from different points of view, these professionals seek to improve the user experience, facilitating faster access to information (informatics), improving the usability and graphic aspect of the content (design) and producing contextualized and credible information (Canavilhas et al., 2015). It is from the joint work of these professionals that more elaborate content is born which responds to the information needs of the most demanding consumers and, above all, to the new generations. As previously mentioned, the survival of journalism depends on its ability to ensure the generational renewal of consumers, as stated before, which can be done using the type of content that most attracts them.

Content is precisely one of the areas where journalism for mobile devices has shown that it is possible to offer something different from the legacy media. Using the mobility, portability and technical characteristics of the devices, formats for smartphones emerged, such as immersive content, namely 3D sound, augmented reality and virtual reality. The use of the word "reality" in the designation of this type of content seeks to convey to users the idea of truth, simulating an environment similar to that in which the action takes place, transporting the user to three-dimensional spaces and enabling sensory experiences (Domínguez-Martín, 2015; Owen et al., 2015). In its connection to journalism, this reality is a form of objectivity, both in the epistemic and ontological strands since it removes the intermediaries and interpretations of the space where the action takes place, freeing the user for a free exploration that transforms him into the individual he feels.

Finally, the economic aspect may have an epistemological influence in journalism as the quality of the content is directly related to the ability to hire human and technological resources. The economic fragility of legacy media motivated by the exhaustion of its business model leads to social discredit (McChesney, 2013; Casero-Ripollés; Izquierdo-Castillo, 2013) which in turn leads to a loss of audience, thus entering a negative spiral: the reduction in revenue leads to cuts in the newsroom, which leads to an increase in the workload for journalists, who resort more to agency information. Thus, there is a clear impoverishment of the journalism produced, also called "churnalism" (Harcup, 2004; Johnston; Forde, 2017), which is limited to recycling information to produce content with low informative value for which users are not willing to pay and which has no social relevance nor constitutes knowledge.

A final word to emphasize that the remarkable growth in the consumption of push news, in other words, content that is characterized by its superficiality, could move journalism away from the characteristics of the sciences that produce knowledge. However, we must never forget that this lower complexity is balanced with greater speed, which responds to the needs of a more accelerated society that requires a greater cadence of information (Meditsch, 1997) and which value this kind of knowledge. The key is to maintain a permanent link between these informative "snacks" (Molyneux, 2018) and contextual journalism, thus functioning as a starting point for consumption and never as an arrival point.

\section{Final notes}

The fact that Web journalism and Mobile journalism share the same channel means that there is a great proximity between the themes discussed in this work. The great difference that separates them relates to the characteristics of access technologies, but still a mobile device is a computer which has greater portability than desktops, laptops and even tablets. Perhaps for this reason, Bui and Moran (2020) claim that more and more digital journalism is becoming mobile.

In a broad perspective, we agree with Salaverría (2019) when he states that the area of digital journalism, as mobile journalism, has become a fertile field for research, presently offering a multiplicity of approaches and methodologies specific to work in this field. The traditional area of journalism, already influenced by Sociology and Psychology, has received expertise knowledge from Design and Informatics, and has managed to transform itself into an area of mutual fertilization. That is why many avenues of research have already pioneered but are still in need of deeper and greater volume research so that meta-research and new theories can be achieved. Several authors (Ekström; Westlund, 2019; Fortunati; O'Sullivan, 2020) identify some of the questions that deserve a deeper and more thoughtful reflection when epistemological and technical issues related to mobile news are discussed.

First of allt, it is interesting to continue developing studies in the field of audiences in order to reinforce understanding of why mobile consumption had such a rapid increase, not only among new generations but across the board. Another important line will be to know if the increase in speed in the circulation of information has an impact on the way people perceive the role of journalism as a form of public opinion.
The joint work of journalists and techno-actors (designers and computer scientists) allows for the production of news content that satisfies the information needs of the most demanding consumers and, above all, of the new generations 
In the field of production, issues related to the changes caused by mobile devices in terms of production costs, the appearance of new professions and the skills demanded from journalists, deserve to be further studied. The conclusions of these works must be analyzed in the context of the new labor relations within companies and their repercussions on the epistemological ties with the profession.

As this area is strongly linked to technology, the opening of new lines of investigation is a constant since mobile journalism refers not only to digital content for smartphones and tablets, but also for glasses and smart watches, among other wearables. In this arena, research in the field of content, namely in terms of languages, formats and genres is fundamental, as it explores its connection to the field of design and usability. Equally important is to use the experimental method to assess the impact of individual consumption on mobility in the perception of users' understanding and to ascertain what to change in the content in order to compensate for any loss of effectiveness motivated by less attention devoted to the content.

All these new devices have two characteristics in common: ubiquity and personal use. This situation opens enormous potential for the collection of reliable big data, one of the traditional problems in journalism research. For this reason, the area of Statistics also acquires greater relevance in the studies to be undertaken in this field. The treatment of these personal data also raises issues of great relevance related to confidentiality, so Ethics is another area called for research in the field of mobile devices.

Finally, the study of new models for the economic viability of journalism are another important field of work, as the quality of the final product depends on the conditions of production, namely the existence of human resources and technical means that allow journalism to develop its social role.

For all these reasons, it is believed that Mobile journalism is an area with great potential for growth in the field of research, in addition to the fact that it brings together a set of characteristics capable of facilitating an approximation between research undertaken in academia and the needs of communication companies facing an unprecedented crisis. Perhaps the solution lies precisely in the joint work between two worlds that have always lived 'back-to-back', but that due to the technological and social acceleration are compelled to cooperate.

\section{References}

Aguado, Juan-Miguel; Castellet, Andreu (2013). “Contenidos digitales en el entorno móvil: mapa de situación para marcas informativas y usuarios". In: Barbosa, Suzana; Mielniczuk, Luciana (org.). Jornalismo e tecnologias móveis, Covilhã: Livros Labcom, pp. 25-50. ISBN: 9789896541019

Aguado, Juan-Miguel; Martínez, Inmaculada J. (2006). “El proceso de mediatización de la telefonía móvil: de la interacción al consumo cultural". Zer, v. 11, n. 20, p. 319-343.

https://ojs.ehu.eus/index.php/Zer/article/view/3770

Ahonen, Tomi T. (2008). Mobile as $7^{\text {th }}$ of the mass media: Cellphone, cameraphone, iPhone, smartphone. London: Futuretext. ISBN: 9780955606953

Aitamurto, Tanja; Aymerich-Franch, Laura; Saldivar, Jorge; Kircos, Catherine; Sadeghi, Yasamin; Sakshuwong, Sukolsak (2020). "Examining augmented reality in journalism: Presence, knowledge gain, and perceived visual authenticity". New media \& society, online first.

https://doi.org/10.1177/1461444820951925

Anderson, Chris (2006). The long tail: Why the future of business is selling less of more. New York: Hyperion. ISBN: 978 1401309664

Anderson, Chris (2009). Free: the future of a radical price. London: Random House Business Books. ISBN: 9781401322908

Andrade, Alice-Oliveira; Silva, Ana-Carmem; Nobre, Itamar-de-Morais (2015). “O uso de smartphones na fotografia jornalística em Natal (Rio Grande do Norte / Brasil)". En: Canavilhas, João; Satuf, Ivan. Jornalismo para dispositivos móveis: produção, distribuição e consumo, Covilhã: Livros Labcom, pp. 179-198. ISBN: 9789896542306

Barbosa, Suzana (2013). "Jornalismo convergente e continuum multimídia na quinta geração do jornalismo nas redes digitais". In: Canavilhas, João (org.). Notícias em mobilidade. Jornalismo na era dos dispositivos móveis. Covilhã: Livros Labcom, pp. 33-54. ISBN: 9789896541026

Bernal, Ana-Isabel (2009). Los nuevos medios de comunicación y los jóvenes. Aproximación a un modelo ideal de medio. Bruselas: Euroeditions. ISBN: 9788493691530 
Bivens, Rena-Kim (2008). "The internet, mobile phones and blogging: How new media are transforming traditional journalism". Journalism practice, v. 2, n. 1, pp. 113-129.

https://doi.org/10.1080/17512780701768568

Blankenship, Justin C. (2016). “Losing their 'mojo'?”. Journalism practice, v. 10, n. 8, pp. 1055-1071.

https://doi.org/10.1080/17512786.2015.1063080

Bowman, Shayne; Willis, Chris (2003). We media - How audiences are shaping the future of news and information. The Media Center at the American Press Institute.

http://www.hypergene.net/wemedia/download/we_media.pdf

Bradshaw, Paul (2014). "Instantaneidade: Efeito da rede, jornalistas mobile, consumidores ligados e o impacto no consumo, produção e distribuição”. In: Canavilhas, João (org.). Webjornalismo: 7 caraterísticas que marcam a diferença. Covilhã: Livros LabCom, pp. 111-136. ISBN: 9789896541446

Brites, Maria-José (2010). “Jovens (15-18 anos) e informação noticiosa: a importância dos capitais cultural e tecnológico". Estudos em comunicação, v. 8, pp.169-192.

http://www.ec.ubi.pt/ec/08/pdf/EC08-2010Dez-10.pdf

Bruns, Axel (2008). Blogs, Wikipedia, Second Life and beyond: From production to produsage. New York: Peter Lang. ISBN: 9780820488677

Bui, Matthew N.; Moran, Rachel E. (2020). "Making the $21^{\text {st }}$ century mobile journalist: Examining definitions and conceptualizations of mobility and mobile journalism within journalism education". Digital journalism, v. 8, n. 1, pp. 145-163. https://doi.org/10.1080/21670811.2019.1664926

Canavilhas, João (2011). “El nuevo ecosistema mediático”. Index comunicación, v. 1, n. 1, pp. 13-24.

https://journals.sfu.ca/indexcomunicacion/index.php/indexcomunicacion/article/view/4

Canavilhas, João (2013). "Contenidos periodísticos en el ecosistema líquido: Entre la convergencia y la divergencia”. In: Irigaray, Fernando; Ceballos, Dardo; Manna, Matias. Webperiodismo en un ecosistema líquido. Rosario: Laborde Libros Editor, pp. 9-24. ISBN: 9789876770453

Canavilhas, João (2015). “Nuevos medios, nuevo ecosistema”. El profesional de la información, v. 24, n. 4, pp. 357-362. https://doi.org/10.3145/epi.2015.jul.01

Canavilhas, João; Pellanda, Eduardo; Piñeiro-Naval, Valeriano; Nunes, Ana-Cecilia B. (2020). “Mobile phones in young people everyday life: case study with Portuguese and Brazilian students". Revista Famecos, v. 27, pp. 1-23. https://doi.org/10.15448/1980-3729.2020.1.35850

Canavilhas, João; Satuf, Ivan (2016). "Who brings the news? Exploring the aggregators apps for mobile devices". In: Aguado, Juan-Miguel; Feijóo, Claudio; Martínez, Inmaculada J. (eds.). Emerging perspectives on the mobile content evolution. IGI Global, pp. 223-241. ISBN: 9781466688384

http://doi.org/10.4018/978-1-4666-8838-4.ch012

Canavilhas, João; Satuf, Ivan; Baccin, Alciane (2016). “El futuro del periodismo está en el ecosistema móvil”. En: Sánchez-Gonzales Hada M. (coord.), Nuevos retos para el periodista innovación, creación y emprendimiento. Valencia: Tirant Humanidades. ISBN: 9788416556151

Canavilhas, João; Satuf, Ivan; Luna, Diógenes; Torres, Vitor (2014). "Jornalistas e tecnoatores: dois mundos, duas culturas, um objetivo". Revista esferas, n. 5, pp. 85-95.

https://portalrevistas.ucb.br/index.php/esf/article/view/5690

Casero-Ripollés, Andreu (2010). "Prensa en internet: nuevos modelos de negocio en el escenario de la convergencia". El profesional de la información, v. 19, n. 6, pp. 595-601.

https://doi.org/10.3145/epi.2010.nov05

Casero-Ripollés, Andreu (2012). "Más allá de los diarios: el consumo de noticias de los jóvenes en la era digital”. Comunicar, n. 39, pp. 151-158.

https://doi.org/10.3916/C39-2012-03-05

Casero-Ripollés, Andreu; Izquierdo-Castillo, Jessica (2013). "Between decline and a new business model: the case of the Spanish newspaper industry". Journal of media business studies, v. 10, 1, pp. 63-78.

https://doi.org/10.1080/16522354.2013.11073560

Castellet, Andreu; Feijóo, Claudio (2013). "Los actores en el ecosistema móvil”. En: Aguado, Juan-Miguel; Feijóo, Claudio; Martínez, Inmaculada J. (coords.). La comunicación móvil: Hacia un nuevo ecosistema digital. Barcelona: Editorial Gedisa, pp. 27-56. ISBN: 9788497847827 
Cevallos, María-del-Carmen (2009). Jóvenes y celulares: las razones de su uso y abuso. https://bit.ly/2KTVfJs

Colussi, Juliana; Assunção-Reis, Thays (2020). "Immersive journalism: a narrative analysis in virtual reality apps". Revista latina de comunicación social, n. 77, pp. 19-32.

https://www.doi.org/10.4185/RLCS-2020-1447

Costera-Meijer, Irene (2007). "The paradox of popularity: How young people experience the news". Journalism studies, v. 8, n. 1, pp. 96-116.

https://doi.org/10.1080/14616700601056874

Courtois, Cédric; Verdegem, Pieter; De-Marez, Lieven (2013). "The triple articulation of media technologies in audiovisual media consumption". Television \& new media, v. 14, n. 5, pp. 421-439.

https://doi.org/10.1177/1527476412439106

Dancy, Jonathan (1985). Epistemologia contemporânea. Lisboa: Edições 70. ISBN: 9789724408118

Da-Silva, Fernando-Firmino (2014). “Smartphones e tablets na produção jornalística”. Âncora, v. 1, n. 1, pp. 23-40. https://periodicos.ufpb.br/ojs2/index.php/ancora/article/view/22735

Da-Silva, Fernando-Firmino (2015). Jornalismo móvel. Salvador: Edufba. ISBN: 9788523213787

De-la-Peña, Nonny; Weil, Peggy; Llobera, Joan; Giannopoulos, Elias; Pomés, Ausiàs; Spanlang, Bernhard; Friedman, Doron; Sánchez-Vives, Maria V.; Slater, Mel (2010). "Immersive journalism: immersive virtual reality for the first-person experience of news". Presence: Teleoperators and virtual environments, v. 19, n. 4, pp. 291-301. https://doi.org/10.1162/PRES_a_00005

Dimmick, John W.; Powers, Angela; Mwangi, Sam; Stoycheff, Elisabeth (2011). "The fragmenting mass media marketplace". In: Lowrey, Wilson; Gade, Peter J. (eds.). Changing the news. The forces shaping journalism in uncertain times London, UK: Routledge, pp. 177-192. ISBN: 9780415871570

Dimmick, John W.; Sikand, Jaspreet; Patterson, Scott J. (1994). "The gratifications of the household telephone: Sociability, instrumentality and reassurance". Communication research, v. 21, n. 5, pp. 643-663.

https://doi.org/10.1177/009365094021005005

Domingo, David (2011). "Managing audience participation. Practices, workflows and strategies”. In: Singer, Jane B.; Domingo, David; Heinonen, Ari; Hermida, Alfred; Paulussen, Steve; Quandt, Thorsten; Reich, Zvi; Vujnovic, Marina. Participatory journalism: Guarding open gates at online newspapers. New York: Wiley-Blackwell, pp. 76-95. ISBN: 9781444 332261

Domínguez-Martín, Eva (2015). “Periodismo inmersivo o cómo la realidad virtual y el videojuego influyen en la interfaz e interactividad del relato de actualidad". El profesional de la información, v. 24, n. 4, pp. 413-423.

https://doi.org/10.3145/epi.2015.jul.08

Ekström, Mats; Westlund, Oscar (2019). Epistemology and journalism. Oxford research encyclopedia, communication. https://doi.org/10.1093/acrefore/9780190228613.013.806

Fidalgo, António; Canavilhas, João (2009). "Todos os jornais no bolso: Pensando o jornalismo na era do celular". In: Rodrigues, Carla (org.). Jornalismo on-line: modos de fazer. Porto Alegre: Editora Sulina, pp. 96-146. ISBN: 9788520505397

Fortunati, Leopoldina; O’Sullivan, John (2020). “Understanding mobile news: looking beyond the lockscreen". Digital journalism, v. 8, n. 1, pp. 164-169.

https://doi.org/10.1080/21670811.2019.1709522

Gant, Diana; Kiesler, Sara (2001). "Blurring the boundaries: Cell phones, mobility, and the line between work and personal life". In: Brown, Barry; Green, Nicola; Harper, Richard (eds.), Wireless world: Social and interactional aspects of the mobile age. London, UK: Springer-Verlag, pp. 121-131. ISBN: 9781447106654

Germen, Murat (2014). "The unstoppable rise of mobile imaging and aesthetics". Proceedings of the EVA London 2014 on Electronic visualisation and the arts.

https://dl.acm.org/doi/10.14236/ewic/eva2014.35

Geser, Hans (2004). Towards a sociological theory of the mobile phone. Sociological Institute. University of Zurich. http://socio.ch/mobile/t_geser1.pdf

Gillmor, Dan (2006). We the media: Grassroots journalism by the people, for the people. Sebastopol: O'Reilly Media. ISBN: 9780596102272

Glaser, Mark (2004). “Collaborative conundrum: Do wikis have a place in the newsroom?”. In: Online journalism review, Sept. http://www.ojr.org/ojr/glaser/1094678265.php 
Goeldi, Andreas (2018). The smartphone revolution: Why the app store was more important than the iPhone. Innospective. https://bit.ly/3/IBu4c

Goggin, Gerard; Hjorth, Larissa (2009). "The question of mobile media”. In: Goggin, Gerad; Hjorth, Larissa (eds.). Mobile technologies: From telecommunications to media. New York, NY: Routledge, pp. 3-8. ISBN: 9780415878432

Gómez-Barroso, José-Luis (2018). “Uso y valor de la información personal: un escenario en evolución”. El profesional de la información, v. 27, n. 1, pp. 5-18.

https://doi.org/10.3145/epi.2018.ene.01

Gong, Jun; Tarasewich, Peter (2004). "Guidelines for handheld mobile device interface design". Proceedings of the 2004 DSI annual meeting, pp. 3751-3756.

Grau, Oliver (2007). Arte virtual: da ilusão à imersão. São Paulo: Editora Sena. ISBN: 9788573595321

Guerrero-García, Virginia; Palomo, Bella (2015). "The crisis of photojournalism: rethinking the profession in a participatory media ecosystem". Communication \& society, v. 28, n. 4, pp. 33-48.

https://doi.org/10.15581/003.28.4.33-48

Harcup, Tony (2004). Journalism principles and practice. London: Sage. ISBN: 9781847872500

Harré, Rom (1984). As filosofias da ciência. Lisboa: Edições 70.

Henshaw, John M. (2006). Does measurement measure up?: How numbers reveal and conceal the truth. Baltimore: John Hopkins University Press. ISBN: 9780801883750

Hermida, Alfred; Thurman, Neil (2008). "A clash of cultures: The integration of user-generated content within professional journalistic frameworks at British newspapers websites". Journalism practice, v. 2, n. 3, pp. 343- 356.

https://doi.org/10.1080/17512780802054538

Huang, Edgar (2009). "The causes of youth's low news consumption and strategies for making youths happy news consumers". Convergence, v. 15, n. 1, pp. 105-122.

https://doi.org/10.1177/1354856508097021

Jarvis, Jeff (2009). What would Google do?. New York: Haper Collins. ISBN: 9780061719912

Jenkins, Henry (2008). Convergence culture. La cultura de la convergencia de los medios de comunicación. Barcelona: Paidós. ISBN: 9788449321535

Jensen, Klaus-Bruhn (2013). “What's mobile in mobile communication?”. Mobile media \& communication, v. 1, n. 1, pp. $26-31$. https://doi.org/10.1177/2050157912459493

Johnston, Jane; Forde, Susan (2017). “Churnalism”. Digital journalism, v. 5, n. 8, pp. 943-946. https://doi.org/10.1080/21670811.2017.1355026

Jukes, Stephen (2013). “A perfect storm”. In: Fowler-Watt, Karen; Allan, Stuart (eds.), Journalism: new challenges. Centre for Journalism \& Communication Research, Bournemouth University, pp. 1-18. ISBN: 9781910042014

Katz, James E.; Aarhus, Mark (2002). Perpetual contact: Mobile communication, private talk, public performance. Cambridge. Cambridge University Press. ISBN: 9780511489471

https://doi.org/10.1017/CB09780511489471

Kischinhevsky, Marcelo (2009). "Cultura da portabilidade. Novos usos do rádio e sociabilidades em mídia sonora”. Observatorio (OBS*) Journal, n. 8, pp. 223-238.

http://obs.obercom.pt/index.php/obs/article/viewArticle/271

Klemens, Guy (2010). The cellphone: The history and technology of the gadget that changed the world. Jefferson McFarland. ISBN: 9780786458677

Kovach, Bill; Rosenstiel, Tom (2014). The elements of journalism. New York: Three Rivers Press ISBN: 9780307346704

Lasen, Amparo (2001). The social shaping of fixed and mobile networks: A historical comparison. Digital World Research Centre, University of Surrey.

http://www.kiwanja.net/database/document/report_mobile_history.pdf

Lauf, Edmund (2001). "Research note: The vanishing young reader. Sociodemographic determinants of newspaper use as a source of political information in Europe, 1980-1998". European journal of communication, v. 16, n. 2, pp. $233-243$. https://doi.org/10.1177/0267323101016002005

Ling, Rich (1997). "One can talk about common manners! The use of mobile telephones in inappropriate situations”. In: Haddon, Leslie, Themes in mobile telephony final report of the COST 248 home and work group.

https://bit.ly/2VzvvEi 
Linger, Richard C. (2002). "Chicas adolescentes y jóvenes adultos varones: dos subculturas del teléfono móvil”. Estudios de juventud, n. 57/02, pp. 33-46.

López-García, Xosé; Silva-Rodríguez, Alba; Direito-Rebollal, Sabela; Vázquez-Herrero, Jorge (2020). “From meta-journalism and post-journalism to total journalism". In: Vázquez-Herrero, Jorge; Direito-Rebollal, Sabela; Silva-Rodríguez, Alba; López-García Xosé (eds.). Journalistic metamorphosis, studies in big data 70. Cham: Springer, pp. 199-207. ISBN: 9783030363147

https://doi.org/10.1007/978-3-030-36315-4_15

Lorente, Santiago (2002). “Juventud y teléfonos móviles. Algo más que una moda”. Estudios de juventud, n. 57/02, pp. 9-24.

Maccise, Diana-Larrea; Marai, Montaser (2017). Mobile journalism. Doha: Al Jazeera Media Training and Development Centre.

https://institute.aljazeera.net/sites/default/files/2018/mobile\%20journalisn\%20english.pdf

Madianou, Mirca; Miller, Daniel (2013). "Polymedia: Towards a new theory of digital media in interpersonal communication". International journal of cultural studies, v. 16, n. 2, pp.169-187.

https://doi.org/10.1177/1367877912452486

McChesney, Robert W. (2013). Digital Disconnect. New York: The New Press. ISBN: 9781620970317

McNair, Brian (1998). The sociology of journalism. Oxford: Oxford University Press. ISBN: 9780340706152

Meditsch, Eduardo (1997). “O jornalismo é uma forma de conhecimento?”. Biblioteca on-line de ciências da comunicação. Covilhã: Universidade da Beira Interior.

http://www.bocc.ubi.pt/pag/meditsch-eduardo-jornalismo-conhecimento.pdf

Meso-Ayerdi, Koldo (2005). “Periodismo ciudadano: voces paralelas a la profesión periodística”. Chasqui, n. 90, pp. 4-15. https://revistachasqui.org/index.php/chasqui/article/view/234

Mielniczuk, Luciana (2013). "O celular afronta o jornalismo”. In: Barbosa, Suzana; Mielniczuk, Luciana (org.). Jornalismo e tecnologias móveis. Covilhã: Livros Labcom, pp. 113-126. ISBN: 9789896541019

Mills, John; Egglestone Paul; Rashid; Omer; Väätäjä, Heli (2012). “MoJo in action: The use of mobiles in conflict, community, and cross-platform journalism". Continuum, v. 26, n. 5, pp. 669-683.

https://doi.org/10.1080/10304312.2012.706457

Molyneux, Logan (2018). “Mobile news consumption”. Digital journalism, v. 6, n. 5, pp. 634-650. https://doi.org/10.10 80/21670811.2017.1334567

Moretzsohn, Sylvia (2002). Jornalismo em "tempo real": O fetiche da velocidade. Rio de Janeiro: Revan. ISBN: 978 8571062467

Nelson, Jacob L. (2019). "The persistence of the popular in mobile news consumption, digital journalism". Digital journalism, v. 8, n. 1, pp. 1-16.

https://doi.org/10.1080/21670811.2019.1612766

Newman, Nic (2012). Reuters Institute digital news report 2012: Tracking the future of news. Reuters Institute for the Study of Journalism: University of Oxford.

http://media.digitalnewsreport.org/wp-content/uploads/2012/05/Reuters-Institute-Digital-News-Report-2012.pdf

Ortega-Gutiérrez, Félix; Humanes, María-Luisa (2000). Algo más que periodistas: sociologia de una profesión. Barcelona: Ariel. ISBN: 8434418142

Owen, Taylor; Pitt, Ferguson; Aronson-Rath, Raney; Milward, James (2015). Virtual reality journalism. Tow Center for Digital Journalism, Columbia Journalism School.

https://www.cjr.org/tow_center_reports/virtual_reality_journalism.php

Palacios, Marcos; Barbosa, Suzana; Da-Silva, Fernando F.; Da-Cunha, Rodrigo (2015). "Jornalismo móvel e inovações induzidas por affordances em narrativas para aplicativos em tablets e smartphones”. In: Canavilhas, João; Satuf, Ivan. Jornalismo para Dispositivos Móveis: produção, distribuição e consumo, Covilhã: Livros Labcom, pp. 7-42. ISBN: 978 9896542306

http://labcom.ubi.pt/livro/137

Pariser, Eli (2011). The filter bubble: What the Internet is hiding from you. New York: Penguin Press. ISBN: 9780141969923

Park, Robert (2008). "A notícia como forma de conhecimento: um capítulo dentro da sociologia do conhecimento". In: Berger, Christa; Marocco, Beatriz (org.). A era glacial do jornalismo: teorias sociais da imprensa, v. 2. Porto Alegre: Sulina, pp. 51-70. ISBN: 9788520504413 
Parry, Roger (2011). The ascent of media: From Gilgamesh to Google via Gutenberg. London: Nicholas Brealey Pub. ISBN: 9781857885705

Paty, Michel (1997). "A idéia da universalidade da ciência e sua crítica filosófica e histórica”. Discurso, n. 28, pp. 7-60. https://doi.org/10.11606/issn.2318-8863.discurso.1997.38018

Pauwels, Luc (2005). "Websites as visual and multimodal cultural expressions: opportunities and issues of online hybrid media research". Media, culture \& society, v. 27, n. 4, pp. 604-613.

https://doi.org/10.1177/0163443705053979

Pauwels, Caroline; Picone, Ike (2012). "The tussle with trust: Trust in the news media ecology". Computer law \& security review, v. 28, pp. 542-550.

https://doi.org/10.1016/j.clsr.2012.07.003

Pedrero-Esteban, Luis-Miguel; Herrera-Damas, Susana (2017). “La notificación push como estrategia informativa de la radio en el entorno digital”. El profesional de la información, v. 26, n. 6, pp. 1100-1107.

https://doi.org/10.3145/epi.2017.nov.09

Pellanda, Eduardo-Campos (2009). “Comunicação móvel: das potencialidades aos usos e aplicações". Em questão, v. 15, n. 1, pp. 89-98.

https://seer.ufrgs.br/EmQuestao/article/view/6478

Perreault, Gregory; Stanfield, Kellie (2019). “Mobile journalism as lifestyle journalism?” Journalism practice, v. 13, n. 3, pp. 331-348.

https://doi.org/10.1080/17512786.2018.1424021

Peters, Chris (2012). “Journalism to go: The changing spaces of news consumption”. Journalism studies, v. 13, n. 5-6, pp. 695-705.

https://doi.org/10.1080/1461670X.2012.662405

Peters, Chris; Broersma, Marcel (eds.) (2013). Rethinking journalism: trust and participation in a transformed news landscape. New York: Routledge. ISBN: 9780415697019

Picard, Robert (2013). Criação de valor e o futuro das organizações jornalísticas. Porto: Editora Media XXI. ISBN: 978989 7290725

Podger, Corinne (2018). Mobile journalism manual: the guide for reporters and newsrooms. Berlin: Konrad Adenauer Stiftung.

https://www.mojo-manual.org

Postman, Neil (1979). Teaching as a conserving activity. New York: Delacorte Press. ISBN: 9780440086512

Quinn, Sally; Oldmeadow, Julian (2013). "The Martini effect and social networking sites: Early adolescents, mobile social networking and connectedness to friends". Mobile media \& communication, v. 1, n. 2, pp. 237-247.

https://doi.org/10.1177/2050157912474812

Raeymaeckers, Karin (2004). "Newspapers editors in search of young readers: Content and layout strategies to win new readers". Journalism studies, v. 5, n. 2, pp. 221-232.

https://doi.org/10.1080/1461670042000211195

Renó, Denis-Porto (2011). "Jornalismo de bolso: A produção de notícias para a blogosfera a partir de telefones móveis". TecCom studies, v. 1, n. 2, pp. 3-9.

http://www.teccomstudies.com/index.php?journal=teccomstudies\&page=article \&op=view\&path\%5B\%5D=122\&path\%5B\%5D=103

Richter, Felix (2019). "Have we passed the peak of the smartphone era?". Statista, 14 Febr. https://www.statista.com/chart/12798/global-smartphone-shipments

Rosen, Jay (2006). "The people formerly known as the audience". Press think, 27 June. http://archive.pressthink.org/2006/06/27/ppl_frmr.html

Saad, Beth (2011). “Estratégias de conteúdo para meios digitais”. In: Quadros, Claudia; Caetano, Kati; Larangeira, Álvaro (orgs.). Jornalismo e convergência: ensino e práticas profissionais. Covilhã: Livros LabCom, pp. 43-65. ISBN: 9789896540630

Salaverría, Ramón (2014). “Multimedialidade: informar para cinco sentidos”. In: Canavilhas, João (org.). Webjornalismo: 7 caraterísticas que marcam a diferença. Covilhã: Livros LabCom, pp. 25-52. ISBN: 9789896541446

Salaverría, Ramón (2019). “Digital journalism: 25 years of research. Review article”. El profesional de la información, v. 28, n. 1, e280101.

https://doi.org/10.3145/epi.2019.ene.01 
Santaella, Lucia (2007). Linguagens líquidas na era da mobilidade. São Paulo: Paulus. https://ria.ufrn.br/jspui/handle/123456789/1037

Sasseen, Jane; Olmstead, Kenny; Mitchell, Amy (2013). “Digital: As mobile grows rapidly, the pressures on news intensify". The state of the news media 2013. The Pew Research Center's project for excellence in news journalism. https://www.pewresearch.org/topics/state-of-the-news-media

Schneider, Henrik (2007). "The reporting mobile - A new platform for citizen media”. In: Nyíri, Kristóf (org.). Mobile studies - paradigms and perspectives. Wien: Passagen Verlag, pp. 159-167. ISBN: 9783851658033

Scoble, Robert; Israel, Shel (2013). Age of context: mobile sensors, data and the future of privacy. Patrick Brewster Press. ISBN: 9781492348436

Scolari, Carlos A. (2008). Las leyes de la interfaz: diseño, ecología, evolución, tecnología. Barcelona: Gedisa. ISBN: 978 8416919932

Schmitz-Weiss, Amy (2015) “Place-based knowledge in the twenty-first century". Digital journalism, v. 3, n. 1, pp. 116131. https://doi.org/10.1080/21670811.2014.928107

Silva-Rodríguez, Alba (2013). “Los cibermedios y los móviles: una relación de desconfianza”. Icono14, v. 11, n. 2, pp. 183- 207.

https://doi.org/10.7195/ri14.v11i2.586

Steensen, Stenn; Westlund, Oscar (2020). What is digital journalism studies. London: Routledge. ISBN: 9789429259555 https://doi.org/10.4324/9780429259555

Steven, Jane (2002). "Backpack journalism is here to stay". Online journalism review, 2 April. https://bit.ly/2LO6G2g

Strong, Catherine R.; Zafra, Norman (2016). "Natural disaster strategic communication: Drone, data and backpack journalism trends". PRism, v. 13, n. 1.

https://www.prismjournal.org/uploads/1/2/5/6/125661607/v13-no1-a5.pdf

Struckmann, Samson; Karnowski, Veronika (2016). "News consumption in a changing media ecology: An MESM-study on mobile news". Telematics and informatics, v. 33, n. 2, pp. 309-319.

https://doi.org/10.1016/j.tele.2015.08.012

Tambosi, Orlando (2003). “Elementos para uma epistemologia do jornalismo". Intercom. Revista brasileira de ciências de comunicação, v. XXVI, n. 2, pp. 40-52.

https://doi.org/10.1590/rbcc.v26i2.1044

Tracy, Marc (2020). "Digital revenue exceeds print for $1^{\text {st }}$ time for New York Times Company". The New York Times, 5 August.

https://nyti.ms/2VE5ELq

Túñez, Miguel (2009). “Jóvenes y prensa en papel en la era de Internet. Estudio de hábitos de lectura, criterios de jerarquía de noticias, satisfacción con los contenidos informativos y ausencias temáticas". Estudios sobre el mensaje periodístico, v. 15, pp. 503-524.

https://revistas.ucm.es/index.php/ESMP/article/view/ESMP0909110503A

Twist, Jo (2005). "Mobiles capture blast aftermath". BBC News, 8 July.

http://news.bbc.co.uk/2/hi/4663561.stm

Usher, Nikki (2018). "Breaking news production processes in US metropolitan newspapers: Immediacy and journalistic authority". Journalism, v. 19, n. 1, pp. 21-36.

https://doi.org/10.1177/1464884916689151

Van-Damme, Kristin; Courtois, Cédric; Verbrugge, Karel; De-Marez, Lieven (2015). "What's APPening to news? A mixed-method audience centred study on mobile news consumption". Mobile media \& communication, v. 3, n. 2, pp. 196-213.

https://doi.org/10.1177/2050157914557691

Walker, Mason (2019). "Americans favor mobile devices over desktops and laptops for getting news". Pew Research Center, 19 Nov.

https://pewrsr.ch/3qsBtF7

Westlund, Oscar (2008). "From mobile phone to mobile device: News consumption on the go". Canadian journal of communication, v. 33, n. 3, pp. 443-463.

https://doi.org/10.22230/cjc.2008v33n3a2004 
Westlund, Oscar (2012). "Producer-centric vs. participation-centric: On the shaping of mobile media". Northern lights, v. 10, n. 1, pp. 107-121.

https://doi.org/10.1386/nl.10.107_1

Westlund, Oscar (2013). "Mobile news: A review and model of journalism in an age of mobile media”. Digital journalism, v. 1 , n. 1 , pp. 6-26.

https://doi.org/10.1080/21670811.2012.740273

Westlund, Oscar; Färdigh, A. Mathias (2011). "Displacing and complementing effects of news sites on newspapers 1998-2009". International journal on media management, v. 13, n. 3, pp. 177-194.

https://doi.org/10.1080/14241277.2011.595020

Wheatley, Dawn; Ferrer-Conill, Raul (2020). "The temporal nature of mobile push notification alerts: A study of European news outlets' dissemination patterns". Digital journalism, ahead-of-print.

https://doi.org/10.1080/21670811.2020.1799425

Wolf, Cornelia; Hohlfeld, Ralf (2012) "Revolution in journalism? Mobile devices as a new means of publishing". In: Matin, Corinne; Von-Pape, Thilo (eds.). Images in mobile communication. Springer, pp. 81-99. ISBN: 9783531931906

Zelizer, Barbie (1995). “Text, talk, and journalistic quoting practices". The communication review, v. 1, n. 1, pp. 33-51. https://doi.org/10.1080/10714429509388250

Zelizer, Barbie (2019). "Why journalism is about more than digital technology". Digital journalism, v. 7, n. 3, pp. $343-335$. https://doi.org/10.1080/21670811.2019.1571932

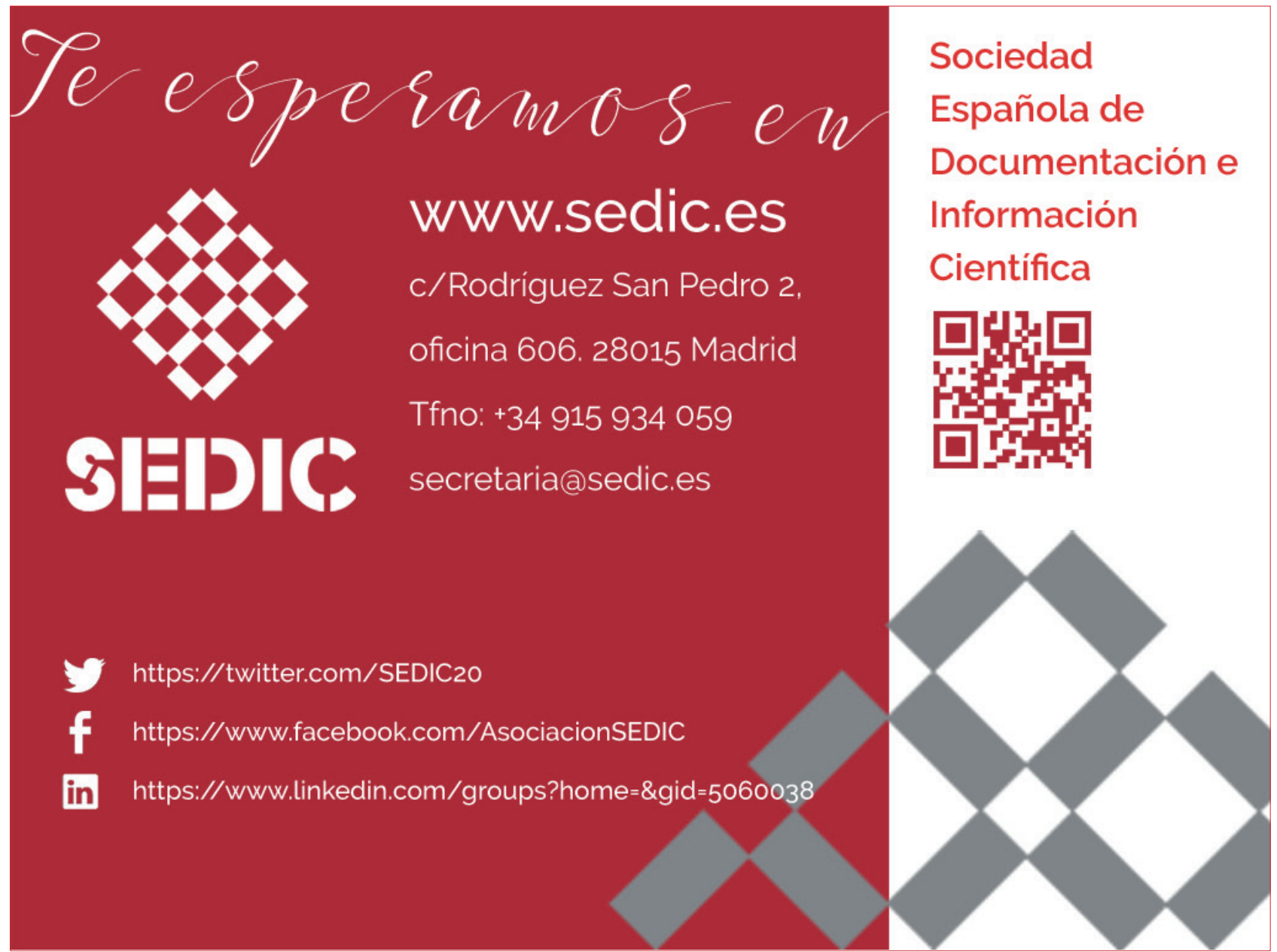

